\title{
Mohawk Language
}

National Cancer Institute

\section{Source}

National Cancer Institute. Mohawk Language. NCI Thesaurus. Code C154033.

An Iroquoian language spoken by people of the Mohawk Nation of Canada and the United States. 